\title{
THE USE OF MULTI-CRITERIA TAXONOMY \\ IN THE STUDY OF OBJECTIVE QUALITY OF LIFE \\ IN POLISH VOIVODESHIPS
}

Iwona Bąk, Ph.D., Associate Prof.

West Pomeranian University of Technology, Szczecin

Faculty of Economics

Department of Mathematical Applications in Economics

Janickiego 31, 71-101 Szczecin, Poland

e-mail:iwona.bak@zut.edu.pl

Beata Szczecińska, Ph.D.

West Pomeranian University of Technology, Szczecin

Faculty of Economics

Department of Systems Analysis and Finance

Janickiego 31, 71-101 Szczecin, Poland

e-mail: beata.szczecinska@zut.edu.pl

Received 1 July 2015, Accepted 27 June 2016

\begin{abstract}
The article attempts to compare the living conditions of the population living in rural communities of West Pomeranian Voivodeship. The analysis used data for 159 indicators in the following areas of life: natural environment, demographics, social aspects, municipal infrastructure and housing, economic aspects, education and schooling, culture and tourism, and transport. The application of a multi-criteria taxonomy method allowed the author to take into account all the spheres of life altogether and to differentiate a group of voivodeships that are similar in terms of the examined phenomenon. On the basis of the conducted study it was found that Poland's regions demonstrate a high degree of differences in terms of the objective quality of life.
\end{abstract}

Keywords: objective quality of life, multi-criteria taxonomy, method unitarisation zeroed

JEL classification: C38, P36 


\section{Introduction}

More and more frequently, the analyses on the quality of life are becoming the focus of attention of researchers from various fields of study and different research centres. The conducting of such research is justified by both the interests of residents, for whom the quality of life constitutes an ever more significant aspect of their life, and the interests of local authorities, who, before they attempt to improve the standard of living of a specific community, first need to diagnose the areas of the greatest import to such community members.

The very concept of quality of life is a complex category, whose objective scope defies an explicit definition and the one which has an interdisciplinary nature. It comprises elements such as: affluence understood as material goods that people possess, health and state of mind, safety, both health-wise (threat to life) and in terms of the loss of property (crime, natural disasters), and in economic sense (financial means of livelihood), condition of the natural environment, spiritual wealth linked with access to education and widely defined culture, sense of belonging to a local community, human relations, and the influence on the decision regarding the life of an individual and a community (Kusterka, 2003, p. 190). Each of these elements has its objective dimension, but the evaluation of quality of life depends on a subjective system of values and the sense of the degree to which one's own needs and aspirations are satisfied. In the international comparisons of quality of life, the most commonly used synthetic indicator describing the level of socio-economic development of each country is HDI. It is based on three basic dimensions: health (life expectancy), education, and income (Jankowska, 2012, pp. 34-35).

Constituting a key research issue of interdisciplinary nature, the analysis of quality of life ought to assume a prominent place in the structure of strategic planning of goals at every governance level (municipalities, counties, and voivodeships). Quality of life and its growth are the supreme objectives for developing the concepts of socio-economic growth, and for creating the instrumentation which enables the implementation of those concepts (Borys, Rogala, 2008, p. 10).

The objective of this paper is isolating the typological groups of Polish voivodeships on a similar level of objective quality of life. The study was conducted with the use of multi-criteria taxonomy.

\section{Concept of quality of life}

The terminology of quality of life is not fully organized, which significantly impedes its quantification in practical studies. Apart from the category of quality of life, other terms that are 
also in use include: living conditions, standard of living, living standard, way of life, or lifestyle. One can distinguish two basic approaches to the interpretation of the phenomenon: evaluative (assessing, comparative), and non-evaluative (descriptive) (Ostasiewicz, 2004; Borys, Rogala, 2008).

In response to the question 'what is the (object's) life?', the evaluative interpretation assigns the contents of 'what is the evaluation of (object's) life?'. Two of its variations can be differentiated (Borys, Rogala, 2008, p. 12):

- positive evaluation (expression of appreciation for life, its usefulness, high degree of needs fulfilment, life ideal, etc.);

- evaluation that may either be positive or negative (low, average, high quality of life, better, worse, more or less developed) - such phrasing constitutes the sense and expression of valuating interpretation.

The essence of a non-evaluating (descriptive) interpretation comes down to defining the distinctions (differences) or similarities of quality of life. It provides a starting point for the formulation of derivative notions of evaluative nature, i.e. objective and subjective quality of life (Kryk, Włodarczyk-Śpiewak, 2006, p. 96).

The objective quality of life is semantically close to the concept of living conditions (or the standard of living). It is defined as the entirety of the objective conditions of infrastructural nature in which a society (social groups, households and individuals) lives. It is chiefly related to the financial situation, the security of subsistence, and the environment of an individual's life (Słaby, 2007, p. 104). This type of quality measurement is carried out with the objective indicators typically assuming the form of natural intensity measures (quantitative or evaluative). It usually encompasses such issues as: the income of households and the manner of the income disposal, food, affluence, housing conditions, the use of social welfare assistance, the education of children, participation in cultural and leisure activities, the use of health care services, the functioning of household members on the job market, unemployment, poverty, disability, and other aspects of social exclusion (Czapiński, Panek, 2009).

On the other hand, the subjective quality of life is related to its perception by individuals (communities) within the framework of a specific value system and in specific social, economic, and political conditions. 


\section{Research material}

The paper presents an analysis of the objective quality of life in Polish voivodeships in 2013. The analysis used data for 159 indicators in the following areas of life (Voivodeships' Statistical Yearbooks, 2014):
A. Natural environment -34 indicators (21\%).
B. Demographics -18 indicators $(11 \%)$.
C. Social aspects (health care, crime rate, civic participation) - 19 indicators (12\%).
D. Municipal infrastructure and housing -19 indicators $(12 \%)$.
E. Economic aspects (job market, business activity) - 27 indicators (17\%).
F. Education and schooling - 21 indicators (13\%).
G. Culture and tourism -11 indicators (7\%).
H. Transport -10 indicators $(6 \%)$.

The above-listed sets of potential diagnostic attributes were verified in respect of two fundamental criteria: the discriminatory capability of the attributes and their informative potential (Panek, 2009, pp. 18-19). When considering the first criterion, a classic variation coefficient was defined and 33 attributes were eliminated from the study for which the value of dispersion did not exceed $10 \%$. In the subsequent step, for each area of life potential diagnostic attributes were reduced. A parametric method proposed by Hellwig (Nowak, 1990) was used for their selection. For this purpose, the matrices of correlation coefficient and potential diagnostic attributes were determined, following which central and isolated attributes were defined. They formed a final set of 55 attributes in the individual spheres of life:

A. Natural environment:

$X_{1}$ - share of arable land in total land area (in \%),

$X_{2}$ - share of conservation areas in total land area (in \%),

$X_{3}$ - share of idle land in total land area (in \%),

$X_{4}$ - total water abstraction in dam $^{3}$ per $1 \mathrm{~km}^{2}$,

$X_{5}$ - untreated industrial and municipal sewage in dam $^{3}$ per $1 \mathrm{~km}^{2}$,

$X_{6}$ - municipal sewage in $\mathrm{kg}$ per 1 resident,

$X_{7}$ - outlays on fixed assets designated to environment conservation in PLN per 1 resident,

$X_{8}$ - outlays on fixed assets designated to water economy in PLN per 1 resident,

$X_{9}$ - electrical energy consumption in kWh per 1 resident,

$X_{10}$ - sale of heating energy in TJ per 1,000 of resident. 
B. Demographics:

$X_{1}$ - divorces per 1,000 residents,

$X_{2}$ - birth rate per 1,000 residents,

$X_{3}$ - deaths caused by digestive system diseases per 100 thou. residents,

$X_{4}$ - infant mortality per 1,000 live births,

$X_{5}$ - population per $1 \mathrm{~km}^{2}$.

C. Social aspects (health care, crime rate, civic participation):

$X_{1}$ - adults validly convicted per 10 thou. residents in a given age group,

$X_{2}$ - physicians per 1,000 residents,

$X_{3}$ - nurses per 1,000 residents,

$X_{4}$ - population per 1 outpatient health care centre,

$X_{5}$ - children at nurseries and day care centres per 1,000 children up to 3 years of age,

$X_{6}$ - places at elderly care centres and welfare centres per 1,000 residents,

$X_{7}$ - individuals drawing welfare benefits per 10 thou. residents.

D. Municipal infrastructure and housing:

$X_{1}$ - sewerage system in $\mathrm{km}$ per $\mathrm{km}^{2}$,

$X_{2}$ - recipients of electrical energy in households in thou. per 1,000 residents,

$X_{3}$ - flats per 1,000 marriages,

$X_{4}$ - surface of permanent market places in thou. $\mathrm{m}^{2}$ per 1,000 residents,

$X_{5}$ - permanent outlets of small retail sale per 1,000 residents.

E. Economic aspects (job market, business activity):

$X_{1}$ - individuals working in agriculture per 1,000 residents,

$X_{2}$ - individuals working in industry per 1,000 residents,

$X_{3}$ - long-term unemployed per 1,000 residents,

$X_{4}$ - individuals working in hazardous conditions in the presence of agents injurious to health in $\%$ of total analysed population,

$X_{5}$ - total income of provinces per 1 resident in PLN,

$X_{6}$ - subjective evaluation of the financial situation of households in $\%$ of a given group of households (good),

$X_{7}$ - investment spending in PLN per 1 resident. 
F. Education and schooling:

$X_{1}$ - number of pupils per 1 primary school,

$X_{2}$ - number of pupils per 1 basic vocational school,

$X_{3}$ - number of pupils per 1 technical secondary school,

$X_{4}$ - number of students per 1 vocational college,

$X_{5}$ - number of primary school pupils per 1 computer with Internet access,

$X_{6}$ - number of junior high school pupils per 1 computer with Internet access,

$X_{7}$ - number of basic vocational school pupils per 1 computer with Internet access,

$X_{8}$ - number of senior high school pupils per 1 computer with Internet access,

$X_{9}$ - number of technical secondary school pupils per 1 computer with Internet access,

$X_{10}$ - net schooling rate in \% in 16-18 age group (senior high schools).

G. Culture and tourism:

$X_{1}$ - book collection in tomes per 1,000 residents,

$X_{2}$ - seats at theatre and musical institution auditoria per 1,000 residents,

$X_{3}$ - museums and museum branches per 1,000 residents,

$X_{4}$ - number of events in a year at culture clubs and centres per 1,000 residents,

$X_{5}$ - tourist facilities per 1,000 residents,

$X_{6}$ - catering outlets per 1,000 residents.

H. Transport:

$X_{1}$ - length of national regular bus transport lines in $\mathrm{km}$ per $100 \mathrm{~km}^{2}$,

$X_{2}$ - road accidents per 1,000 residents,

$X_{3}$ - number of accident fatalities per 100 thou. residents,

$X_{4}$ - municipal public transport lines in $\mathrm{km}$ per $\mathrm{km}^{2}$,

$X_{5}$ - places in municipal public transport vehicles in thou. per 1,000 residents.

In the analysis of heterogeneous phenomena based on multiple attributes, it is necessary to differentiate their nature (Balicki, 2009, pp. 319-320). There are positive characteristics (stimulants), negative ones (destimulants), and neutral ones (neutral variables). The obtained set of attributes included stimulants, whose high values are favourable from the point of view of the nature of the analysed phenomenon, as well as destimulants, for which low values are desirable. Table 1 presents the diagnostic attributes regarding all the examined spheres of life divided into stimulants and destimulants. 
Table 1. Division of diagnostic attributes regarding the individual areas of life into stimulants and destimulants

\begin{tabular}{|l|c|c|}
\hline \multicolumn{1}{|c|}{ Areas of life } & Stimulants & Destimulants \\
\hline Natural environment (A) & $X_{1}, X_{2}, X_{7}, X_{8}$ & $X_{3}, X_{4}, X_{5}, X_{6}, X_{9}, X_{10}$ \\
\hline Demographics (B) & $X_{2}$ & $X_{1}, X_{3}, X_{4}, X_{5}$ \\
\hline Social aspects (C) & $X_{2}, X_{3}, X_{5}, X_{6}, X_{8}$ & $X_{1}, X_{4}, X_{7}$ \\
\hline Municipal infrastructure and housing (D) & $X_{1}, X_{2}, X_{3}, X_{4}, X_{5}$ & - \\
\hline Economic aspects (E) & $X_{1}, X_{2}, X_{5}, X_{6}, X_{7}$ & $X_{3}, X_{4}$, \\
\hline Education and schooling (F) & $X_{10}$ & $X_{1}, X_{2}, X_{3}, X_{4}, X_{5}, X_{6}, X_{7}, X_{8}, X_{9}$ \\
\hline Culture and tourism (G) & $X_{1}, X_{2}, X_{3}, X_{4}, X_{5}, X_{6}$ & $X_{2}, X_{3}$ \\
\hline Transport (H) & $X_{1}, X_{4}, X_{5}$ & \\
\hline
\end{tabular}

Source: own study.

\section{Multi-criteria taxonomy}

The use of multi-criteria taxonomy requires the application of the following procedure (Nowak, 1990, pp. 130-135; Malina, 2004, pp. 139-147):

1. $\mathbf{D}^{\mathbf{K}}$ distance matrices are defined for each of the distinguished classification criteria of $K_{l}(l=1, \ldots, r)$, so that $d_{i j}^{k}$ distances assume the values of $[0,1]$ interval, and for that purpose the zero unitarization method can be used in line with the following formula (Kukuła, 2000, pp. 60-92):

for the stimulant

$$
z_{i j}=\frac{x_{i j}-\min _{i} x_{i j}}{\max _{i} x_{i j}-\min _{i} x_{i j}}, \quad \max _{i} x_{i j} \neq \min _{i} x_{i j}
$$

$$
\text { for the destimulant } \quad z_{i j}=\frac{\max _{i} x_{i j}-x_{i j}}{\max _{i} x_{i j}-\min _{i} x_{i j}}, \quad \max _{i} x_{i j} \neq \min _{i} x_{i j}
$$

2. A threshold value is defined for distance $d^{*}$. The value is usually defined in accordance with the following formula:

$$
d^{*}=\min _{i} \max _{j}\left\{d_{i j}\right\}
$$

3. For each classification criterion, $\mathbf{C}^{\mathbf{K}}$ affinity matrix of $(n \times n)$ dimension is defined, whose elements $c_{i j}^{K}(i, j=1, \ldots, n)$ are equal to:

$$
c_{i j}^{K}=1 \text { for } d_{i j} \leq d^{*}
$$




$$
c_{i j}^{K}=0 \text { for } d_{i j}>d^{*}
$$

If inequality $d_{i j} \leq d^{*}$ is satisfied, the objects designated as $i$ and $j$ are deemed as similar in terms of the examined criterion. If, however, an opposite condition is satisfied, the relevant objects are treated as dissimilar for value $d^{*}$, thus the affinity measure of $c_{i j}$ will equal zero.

4. A final $\mathbf{C}_{(\mathrm{n} \times \mathrm{n})}$ affinity matrix is determined among the analysed units. $c_{i j}$ elements of $\mathbf{C}$ matrix are equal to the product of relevant elements of $\mathbf{C}^{\mathbf{K}}$ matrix for all the analysed criteria, i.e.:

$$
c_{i j}=\prod_{K=1}^{r} c_{i j}^{K}
$$

It means that $c_{i j}=1(i, j=1, \ldots, n)$ if each of $c_{i j}^{K}$ elements corresponding to it in $\mathbf{C}^{\mathbf{K}}$ matrices is equal to one, and $c_{i j}=0$ if at least one of the $c_{i j}^{K}$ elements corresponding to it is equal to zero. According to the above, two objects are considered to be similar to one another simultaneously on account of all the criteria if they are similar to one another separately on account of those individual criteria. On the other hand, two objects are considered to be dissimilar on account of all the examined criteria if they are not similar to one another even on account of one of such criteria. The adoption of a given algorithm allows to determine a large number of small sized groups (one- and two-element groups). It can then be assumed that the elements of $\mathbf{C}$ matrix are equal to 1 if the sum of the corresponding elements of $\mathbf{C}^{\mathbf{K}}$ affinity matrix for individual criteria is at least equal to $3 / 4$ of the sum of all the differentiated criteria. Otherwise, the elements of C matrix are equal to zero (Malina, 2004, p. 145).

5. Groups of similar elements are classified and identified in terms of the examined criteria using e.g. vector elimination method to that aim (Panek, 2009, pp. 154-160; Wawrzyniak, 2012, p. 98; Malina, 2004, pp. 60-62). A starting point for the method is a change of final $\mathbf{C}_{(\mathrm{n} \times \mathrm{n})}$ affinity matrix into a $\mathbf{C}_{(\mathrm{n} \times \mathrm{n})}^{*}$ dissimilarity matrix. The course of the above-mentioned method is as follows:

a) on the basis of $\mathbf{C}^{*}$ matrix, a $\boldsymbol{c}_{0}$ column vector is created with $n$ components, each of which is a sum of the previous raw of that matrix,

b) the raw is eliminated from $\mathbf{C}^{*}$ matrix along with a corresponding column for which $\boldsymbol{c}_{0}$ vector component has a maximum value; if $\boldsymbol{c}_{0}$ vector contains several components whose value reaches maximum, such a raw and column are eliminated, for instance, the one of the lowest or the highest number, 
c) the activities presented in a) and b) are repeated until $\boldsymbol{c}_{0}$ vector components are equal to zero,

d) the objects corresponding to the rows and columns that have not been eliminated and still remain in $\mathbf{C}^{*}$ matrix form the first sub-group,

e) $\mathbf{C}^{*}(\mathbf{1})$ matrix and $\boldsymbol{c}_{0}(1)$ vector are created for the remaining (eliminated) objects, then using the procedure described in a) to d) we arrive at subsequent groups of objects similar in terms of their structure, and the procedure ends once all the elements from the basic set have been grouped.

For each of the eight areas of life: natural environment (A), demographics (B), social aspects (C), municipal infrastructure and housing (D), economic aspects (E), education and schooling (F), culture and tourism $(\mathrm{G})$, and transport $(\mathrm{H})$, distance matrices $\mathbf{D}^{\mathbf{A}}, \mathbf{D}^{\mathbf{B}}, \mathbf{D}^{\mathbf{C}}, \mathbf{D}^{\mathbf{D}}$, $\mathbf{D}^{\mathbf{E}}, \mathbf{D}^{\mathbf{F}}, \mathbf{D}^{\mathbf{G}}, \mathbf{D}^{\mathbf{H}}$ were determined, and on their basis so were similarity matrices $\mathbf{C}^{\mathbf{A}}, \mathbf{C}^{\mathbf{B}}, \mathbf{C}^{\mathbf{C}}$, $\mathbf{C}^{\mathbf{D}}, \mathbf{C}^{\mathbf{E}}, \mathbf{C}^{\mathbf{F}}, \mathbf{C}^{\mathbf{G}}, \mathbf{C}^{\mathbf{H}}$. Based on the elements of those matrices, a final similarity matrix $\mathbf{C}$ was determined, assuming that the sum of corresponding elements of similarity matrices $\mathbf{C}^{\mathbf{K}}$ for individual criteria is at least equal to 6 (3/4 out of 8 criteria). The matrix served as the basis for distinguishing typological groups of the voivodeships that are similar in respect of all the criteria. The vector elimination method was applied to that aim in accordance with the procedure described in point 5 of this sub-chapter. In this manner, the voivodeships have been assigned into six groups as follows:

- group I: Kuyavian-Pomeranian, Lublin, Podkarpackie, Podlaskie, Świętokrzyskie, Warmian-Masurian, Greater Poland,

- group II: Lower Silesian, Pomeranian, West Pomeranian,

- group III: Łódź, Masovian,

- group IV: Lubusz, Opole,

- group V: Lesser Poland,

- group VI: Silesian.

The large number of the distinguished typological groups resulted from the fact that the assignment of the individual voivodeships to a specific group was often dependent on just one diagnostic attribute whose level distinctly differentiated one object from the other. For that reason, the author decided to conduct a detailed analysis of the diagnostic attributes characterizing the objective quality of life. In the first stage of the analysis, on the basis of the value of a variation coefficient, $\omega_{i}$ measures were determined, which can be interpreted as weights defining relative significance of the individual diagnostic attributes. The measures were determined with the following formula (Nowak, 1990, pp. 34-35): 


$$
\omega_{i}=\frac{V_{i}}{\sum_{i=1}^{n} V_{i}} \times 100
$$

It occurred that for the analysis of the objective quality of life, the following attributes are of greatest importance: untreated industrial and municipal sewage in dam $^{3}$ per $1 \mathrm{~km}^{2}(18.6 \%)$, birth rate $(13.7 \%)$, municipal public transport lines in $\mathrm{km}$ per $\mathrm{km}^{2}(10.3 \%)$, tourist facilities per 1,000 residents $(5.5 \%)$. Average values were calculated for the above-listed attributes in the individual typological groups. Figures 1-4 demonstrate the average levels of the selected attributes that cause significant differences among the groups.

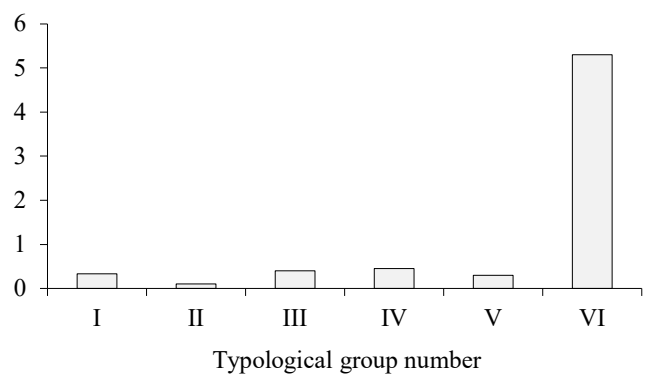

Figure 1. The average level of industrial and municipal waste in the typological groups Source: own study.

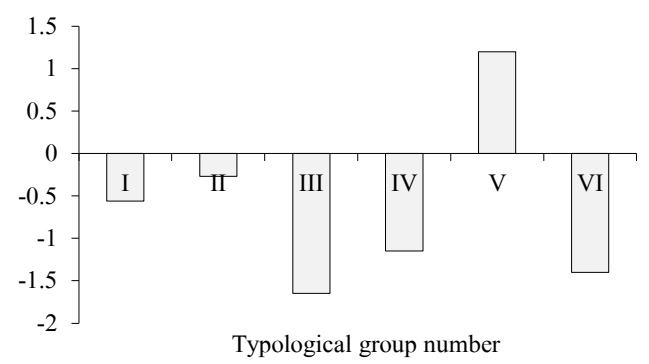

Figure 2. The average level of birth rate in the typological groups

Source: own study. 


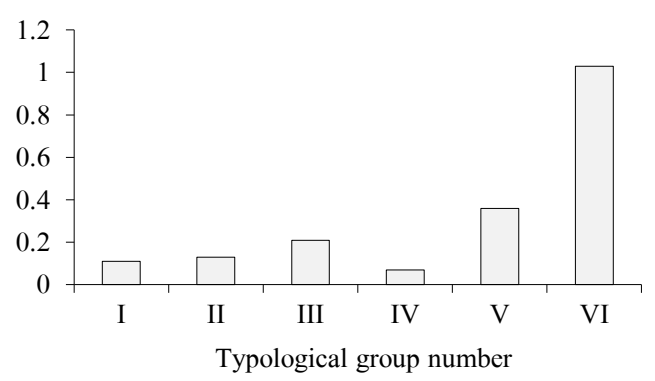

Figure 3. The average length of public transport lines in the typological groups Source: own study.

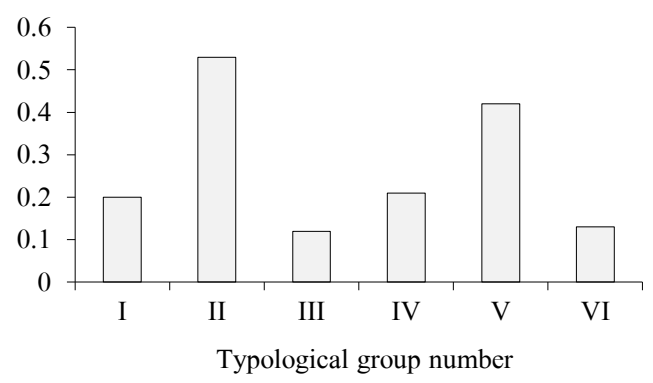

Figure 4. The average number of tourist facilities in the typological groups Source: own study.

The analysis of the remaining diagnostic attributes further indicates that they show at times significant differences with regard to individual objects. Despite the considerable diversification of the Polish voivodeships in terms of the indicators describing the examined spheres of life, one can demonstrate certain regularities within the scope of the designated typological groups. Seven voivodeships were assigned to the most numerous group I. In those voivodeships, the number of the long-term unemployed was above the national average (with the exception of Greater Poland Voivodeship), whereas the number of tourist accommodation facilities (excluding Warmian-Masurian Voivodeship) and a subjective evaluation of the financial situation of the residents (excluding Podlaskie Voivodeship) clearly diverged unfavourably from the average for all the examined objects.

The second group contained objects of well-developed tourist infrastructure and the positive, subjective evaluation of the financial situation of households. Those voivodeships also 
featured lower spending on fixed assets designated to environment conservation and the lower number of individuals working in agriculture than the national average. Also, a net schooling rate (in \%) in the age group 16 to 18 assumed lower than average values for the entire community.

Łódź and Masovian Voivodeships (group III) featured the highest share of arable land in total land area. The highest electrical energy and heating energy consumption per 1,000 residents was recorded in the regions. The voivodeships boasted well-developed municipal public transport (an above-average indicator of the number of places on public transport vehicles per thou. of residents), but, at the same time, they showed unfavourable figures in terms of the number of fatalities in accidents per $100 \mathrm{k}$. residents. A well-developed health care system (an above-average number of physicians and nurses per 1,000 residents) and education system (a very high net schooling rate in the group of senior high school pupils) earns them a high mark.

The lowest number of physicians with simultaneously the highest infant mortality rate per 100 live births is a negative characteristic of the voivodeships assigned to group IV (Opole and Lubusz Voivodeships). The number of the individuals working in industry per 1,000 residents and the voivodeship income per capita showed the most favourable figures in relation to the average for all the objects analysed.

The remaining two groups formed one-element sets. Lesser Poland Voivodeship (group V) ranked high in terms of: outlays on fixed assets designated to the water economy, infant mortality rate, long-term unemployment rate, crime rate, number of museums and museum branches per 1,000 residents. On the other hand, a large number of pupils per one secondary technical school, and poor access of basic vocational and secondary technical schools to computer equipment were the negative characteristics of the region.

Silesian Voivodeship (group VI) featured the highest population density, considerable environment pollution, the highest rate of employment in hazardous conditions in the presence of agents injurious to health alongside a very high number of deaths caused by digestive system diseases. The voivodeship boasts a well-developed municipal public transport grid and sewerage network. The voivodeship recorded the lowest number of fatalities in accidents.

\section{Conclusions}

On the basis of the conducted study, it was found that Poland's regions demonstrate a high degree of differences in terms of the objective quality of life. The application of a multi-criteria taxonomy method allowed the author to take into account all the spheres of life altogether, and to differentiate a group of the voivodeships that are similar in terms of the examined 
phenomenon. It needs to be emphasised that the majority of the voivodeships belonging to the same typological group are neighbouring regions. Group I, which was the most numerous, comprises the voivodeships located in the central and eastern part of Poland. The voivodeships of the north-western regions (with the exclusion of Lubusz Voivodeship) form a homogenous group, namely: Pomeranian, West Pomeranian, and Lower Silesian. Lesser Poland and Silesian Voivodeships constitute separate, one-element groups, which proves that the objective quality of life of their residents differs considerably from the remaining regions of Poland.

The obtained results of typological grouping can be debatable, because they were generated on the basis of a set of diagnostic attributes selected in a formal and statistical manner. If other input attributes and methods were applied in their selection, the composition of typological groups might be different.

\section{References}

Balicki, A. (2009). Statystyczna analiza wielowymiarowa i jej zastosowania społecznoekonomiczne. Gdańsk: Wydawnictwo Uniwersytetu Gdańskiego.

Borys, T., Rogala, P. (2008). Jakość życia na poziomie lokalnym-ujęcie wskaźnikowe. Warszawa: Program Narodów Zjednoczonych ds. Rozwoju.

Czapiński, J., Panek, T. (2009). Diagnoza społeczna 2009. Warunki i jakość życia Polaków. Warszawa: Zakład Wydawnictw Statystycznych.

Jankowska, E. (2012). Zastosowanie wskaźnika rozwoju społecznego HDI do oceny sytuacji społeczno-gospodarczej krajów Unii Europejskiej w latach 2004-2011. Toruńskie Studia Międzynarodowe, 1 (5).

Kryk, B., Włodarczyk-Śpiewak, K. (2006). Wybrane aspekty jakości życia na przykładzie województwa zachodniopomorskiego. In: D. Kopycińska (ed.), Zachowania rynkowe gospodarstw domowych i przedsiębiorstw w okresie transformacji systemowej w Polsce. Szczecin: Katedra Mikroekonomii.

Kukuła, K. (2000). Metoda unitaryzacji zerowanej. Warszawa: PWN.

Kusterka, J. (2003). Jakość życia w aspekcie wybranych wskaźników ekorozwoju. In: J. Tomczyk-Tołkacz (ed.), Jakość życia w perspektywie nauk humanistycznych, ekonomicznych i ekologii. Jelenia Góra: Akademia Ekonomiczna we Wrocławiu.

Malina, A. (2004). Wielowymiarowa analiza przestrzennego zróżnicowania struktury gospodarki Polski wedtug województw. Kraków: AE w Krakowie. 
Nowak, E. (1990). Metody taksonomiczne w klasyfikacji obiektów społeczno-gospodarczych. Warszawa: PWE.

Ostasiewicz, W. (ed.) (2004). Ocena i analiza jakości życia. Wrocław: Wydawnictwo Akademii Ekonomicznej im. Oskara Lanego we Wrocławiu.

Panek, T. (2009). Statystyczne metody wielowymiarowej analizy porównawczej. Warszawa: SGH w Warszawie - Oficyna Wydawnicza.

Roczniki Statystyczne Województw (2014). Urzędy Statystyczne.

Słaby, T. (2007). Poziom i jakość życia. In: T. Panek (ed.), Statystyka społeczna. Warszawa: PWE.

Wawrzyniak, K. (2012). Podobieństwo powiatów województwa zachodniopomorskiego pod względem struktury bezrobotnych według wykształcenia w 2010 roku. Folia Pomeranae Universitatis Technologiae Stetinensis, Oeconomica, 285 (62). 